\title{
Treatment of gonorrhoea using a combination of intramuscular and oral ampicillin
}

\author{
E. STOLZ AND H. J. J. KERKKAMP \\ From the Department of Dermatology and the Bacteriological Laboratory, Faculty of Medicine, Erasmus \\ University, Rotterdam, Netherlands
}

Recent studies have proved that the treatment of uncomplicated gonorrhoea with oral ampicillin, administered either in a single dose of $2 \mathrm{~g}$. plus $1 \mathrm{~g}$. probenecid or $2 \mathrm{~g}$. divided into two doses at an interval of $5 \mathrm{hrs}$, is an effective alternative to conventional treatment with a single intramuscular injection of $1.2 \mathrm{~m} . u$. procaine penicillin plus $1 \mathrm{~m} . \mathrm{u}$. sodium penicillin G (Gundersen, Ødegaard, and Gjessing, 1969; Eriksson, 1970 a,b, 1971). Other regimens of ampicillin treatment are reviewed by Willcox, Woodcock, Latto, John, Redmond, Parker, Rees and Cobbold (1973).

Ampicillin given by intramuscular injection is less frequently used in the treatment of gonorrhoea. Kercull (1968) reported a primary cure rate of 95 per cent. in acute gonorrhoea in military patients in Vietnam, using $1 \mathrm{~g}$. ampicillin daily for two or three days. In the Far East, Keys, Halverson, and Clarke (1969) reported a failure rate of only 1 per cent. with an intramuscular dose of $2 \mathrm{~g}$. ampicillin together with $1 \mathrm{~g}$. probenecid orally.

In this study we have tested the efficacy of $1 \mathrm{~g}$. ampicillin intramuscularly in combination with an oral dose of $2 \mathrm{~g}$. ampicillin taken $4 \mathrm{hrs}$ later.

In order to find out if there was a correlation between therapeutic failures and the minimum inhibitory concentrations (MICs) for ampicillin of the strains of $N$. gonorrhoeae isolated, the MICs for ampicillin were estimated before and, in the cases of therapeutic failure, also after treatment. In addition, ampicillin serum levels were measured in six male patients.

\section{Patients and methods}

The study included 619 outpatients with uncomplicated urogenital or rectal gonorrhoea; 289 were male civilians, 204 were female civilians, and 126 were sailors.

Six of these patients were excluded. One developed an urticarial rash and two had a drop in blood pressure (but not real shock) after the ampicillin injection. These three patients were not given oral ampicillin. Three other patients admitted that they forgot to take the oral ampicil- lin. Of the remaining 613 patients, 286 were male civilians, 202 were female civilians, and 125 were sailors; they all received $1 \mathrm{~g}$. ampicillin intramuscularly and took $2 \mathrm{~g}$. ampicillin by mouth $4 \mathrm{hrs}$ later.

Diagnosis was based on the results of Gram-stained smears and cultures from the urethra in males and from the cervix and urethra in females. Culture was performed on material from the rectum in all females and in eight homosexual males. Specimens were cultured on a selective medium (Thayer and Martin, 1966). Sensitivity tests for ampicillin using the agar-dilution method (Ericsson and Sherris, 1971) were performed on all positive cultures. Strains with MICs of ampicillin $\geqslant 0 \cdot 16 \mu \mathrm{g} . / \mathrm{ml}$. were denoted as relatively resistant.

Female patients were asked to return after $1,2,6$, and 12 weeks, and male patients after 1 and 2 weeks. Smears and cultures were taken at each visit. The criterion for a satisfactory result was two consecutive negative examinations in the first 2 weeks after treatment.

Any patient with a recurrence within 2 weeks who admitted re-exposure to risk of infection, was considered to have been re-infected. Any patient with a recurrence after 2 weeks was also considered to have been re-infected.

In six male volunteers, all with gonococcal urethritis, specimens of serum were assayed by means of the cylinder plate method using Sarcina lutea NCTC 8340 as test organism. (Michel, van Waardhuizen, and Kerrebijn, 1973).

The volunteers satisfied the following conditions: Age between 20 and 40 years, weight between 75 and $80 \mathrm{~kg}$., height between 170 and $190 \mathrm{~cm}$., serum creatinine within the normal range and no history of renal or gastrointestinal disease.

Specimens of serum were taken just before ampicillin treatment started and $15 \mathrm{~min}$., $30 \mathrm{~min}$., and 1, 2, and $4 \mathrm{hrs}$ after the injection. After the oral treatment further samples were taken after $30 \mathrm{~min}$., and 1, 2, 4, and $6 \mathrm{hrs}$.

\section{Results}

The follow-up achieved is presented in Table I.

Of the 613 patients treated, 142 (23.2 per cent.) did not return for follow-up within 2 weeks, whereas 54 (8.8 per cent.) returned after a longer interval than 2 weeks, but within 3 months. Sailors who did not return for any follow-up within 2 weeks ( 56 per cent.) were not considered to be genuine defaulters. In most cases their ships had to leave Rotterdam and so 
TABLE I Follow-up of ampicillin-treated patients

\begin{tabular}{|c|c|c|c|c|c|c|c|c|}
\hline \multirow{2}{*}{ Follow-up } & \multicolumn{2}{|c|}{ Male civilians } & \multicolumn{2}{|c|}{ Female civilians } & \multicolumn{2}{|c|}{ Sailors } & \multicolumn{2}{|c|}{ Total } \\
\hline & No. & Per cent. & No. & Per cent. & No. & Per cent. & No. & Per cent. \\
\hline $\begin{array}{l}\text { Within } 2 \text { wks } \\
\text { Later than } 2 \text { wks but within } 3 \text { mths } \\
\text { No follow-up }\end{array}$ & $\begin{array}{r}192 \\
35 \\
59\end{array}$ & $\begin{array}{l}67 \cdot 1 \\
12 \cdot 2 \\
20 \cdot 6\end{array}$ & $\begin{array}{r}172 \\
17 \\
13\end{array}$ & $\begin{array}{r}85 \cdot 1 \\
8 \cdot 4 \\
6 \cdot 4\end{array}$ & $\begin{array}{r}53 \\
2 \\
70\end{array}$ & $\begin{array}{r}42 \cdot 4 \\
1 \cdot 6 \\
56 \cdot 0\end{array}$ & $\begin{array}{r}417 \\
54 \\
142\end{array}$ & $\begin{array}{r}68 \cdot 0 \\
8 \cdot 8 \\
23 \cdot 2\end{array}$ \\
\hline Total & 286 & 99.9 & 202 & 99.9 & 125 & $100 \cdot 0$ & 613 & $100 \cdot 0$ \\
\hline
\end{tabular}

it was impossible for them to return. The percentage of patients who returned within 2 weeks for follow-up was highest among female civilians $(85 \cdot 1$ per cent.) and lowest among sailors ( $42 \cdot 2$ per cent.); however, a considerable disparity was observed between female and male civilian patients also ( $85 \cdot 1$ per cent. and $67 \cdot 1$ per cent. respectively).

Strains of $N$. gonorrhoeae could not be tested for sensitivity in all patients. In some cases the culture was negative and the Gram-stained smear positive. In other cases cultures were positive, but sensitivity testing could not be carried out because the strains did not survive.

In 388 (93.0 per cent.) of the 417 patients who returned within 2 weeks, the strains of $N$. gonorrhoeae had been isolated before treatment and could be tested for sensitivity. The percentages for male civilians, female civilians, and sailors were $91 \cdot 1$, 95.3 , and 92.5 per cent. respectively.

MICs of ampicillin for all strains of $N$. gonorrhoeae tested were in the range of 0.005 to $0.64 \mu \mathrm{g} . / \mathrm{ml}$.

Table II shows the numbers and percentages of strains relatively resistant $(R R)$ to ampicillin (MIC $\geqslant 0.16 \mu \mathrm{g} . / \mathrm{ml}$.) among strains of $N$. gonorrhoeae isolated in the three patient groups.

The percentage of strains relatively resistant to ampicillin was lowest among those isolated from patients who returned within 2 weeks and, with the exception of the male civilians, highest among those isolated from patients who did not return for followup. The greatest difference was found between strains isolated from sailors who returned within 2 weeks (53.1 per cent. RR to ampicillin) and strains isolated from sailors who did not return at all $(74 \cdot 1$ per cent. RR to ampicillin). No satisfactory explanation could be found for this difference. A higher percentage of strains relatively resistant to ampicillin was found in sailors than in male and female civilians. This finding has been noted in previous studies (Stolz, Zwart, and Michel, 1974; Wols-van der Wielen, 1971).

In Table III, relapses and re-infections in patients who returned for follow-up within two weeks after treatment are recorded.

TABLE II Strains relatively resistant $(R R)$ to ampicillin $(M I C \geqslant 0 \cdot 16 \mu g . / m l$.) among strains of $\mathrm{N}$. gonorrhoeae isolated in the three patient groups

\begin{tabular}{|c|c|c|c|c|c|c|c|c|}
\hline \multirow{2}{*}{ Follow-up } & \multicolumn{2}{|c|}{$\begin{array}{l}M C^{\text {a }} \text { strains } R R \\
\text { to ampicillin }\end{array}$} & \multicolumn{2}{|c|}{$\begin{array}{l}F C^{\mathrm{b}} \text { strains } R R \\
\text { to ampicillin }\end{array}$} & \multicolumn{2}{|c|}{$\begin{array}{l}S^{c} \text { strains } R R \\
\text { to ampicillin }\end{array}$} & \multicolumn{2}{|c|}{$\begin{array}{l}\text { Total strains } R R \\
\text { to ampicillin }\end{array}$} \\
\hline & No. & $\begin{array}{l}\text { Per cent. of all } \\
M C \text { strains }\end{array}$ & No. & $\begin{array}{l}\text { Per cent. of all } \\
F C \text { strains }\end{array}$ & No. & $\begin{array}{l}\text { Per cent. of all } \\
S \text { strains }\end{array}$ & No. & $\begin{array}{l}\text { Per cent. of all } \\
\text { strains }\end{array}$ \\
\hline $\begin{array}{l}\text { Within } 2 \text { wks } \\
\text { later than } 2 \text { wks but within }\end{array}$ & 62 & $35 \cdot 5$ & 53 & $32 \cdot 3$ & 26 & $53 \cdot 1$ & 141 & $36 \cdot 4$ \\
\hline $\begin{array}{l}3 \text { mths } \\
\text { No follow-up }\end{array}$ & $\begin{array}{l}16 \\
21\end{array}$ & $\begin{array}{l}50 \cdot 0 \\
42 \cdot 0\end{array}$ & $\begin{array}{l}6 \\
5\end{array}$ & $\begin{array}{l}35 \cdot 2 \\
38 \cdot 5\end{array}$ & $\begin{array}{r}1 \\
51\end{array}$ & $\begin{array}{l}50 \cdot 0 \\
74 \cdot 1\end{array}$ & $\begin{array}{l}23 \\
77\end{array}$ & $\begin{array}{l}45 \cdot 1 \\
58 \cdot 4\end{array}$ \\
\hline Total & 99 & 38.5 & 64 & 32.9 & 78 & $65 \cdot 0$ & 241 & $42 \cdot 3$ \\
\hline
\end{tabular}

${ }^{\mathrm{a}} \mathrm{MC}=$ male civilian $\quad{ }^{\mathrm{b}} \mathrm{FC}=$ female civilian $\quad{ }^{\mathrm{c} S}=$ sailor

TABLE III Relapses and re-infections among patients who returned for follow-up with 2 weeks

\begin{tabular}{|c|c|c|c|c|c|c|c|c|}
\hline \multirow{2}{*}{ Result } & \multicolumn{2}{|c|}{ Male civilians } & \multicolumn{2}{|c|}{ Female civilians } & \multicolumn{2}{|c|}{ Sailors } & \multicolumn{2}{|c|}{ Total } \\
\hline & No. & Per cent. & No. & Per cent. & No. & Per cent. & No. & Per cent. \\
\hline $\begin{array}{l}\text { Relapses } \\
\text { Re-infections } \\
\text { Relapses and re-infections }\end{array}$ & $\begin{array}{l}4 \\
5 \\
9\end{array}$ & $\begin{array}{l}2 \cdot 1 \\
2 \cdot 6 \\
4 \cdot 7\end{array}$ & $\begin{array}{l}- \\
4\end{array}$ & $\begin{array}{l}- \\
2 \cdot 3\end{array}$ & $\begin{array}{l}-1 \\
1\end{array}$ & $\begin{array}{l}- \\
1 \cdot 9\end{array}$ & $\begin{array}{r}4 \\
10 \\
14\end{array}$ & $\begin{array}{l}1 \cdot 0 \\
2 \cdot 4 \\
3 \cdot 4\end{array}$ \\
\hline Total number of patients examined within 2 wks & 192 & $100 \cdot 0$ & 172 & $100 \cdot 0$ & 53 & $100 \cdot 0$ & 417 & $100 \cdot 0$ \\
\hline
\end{tabular}


Relapses were found in only four male civilians. The relapse rate was 2.1 per cent. in male civilians and 1.0 per cent. in all patients. Thus the cure rate was 97.9 per cent. in male civilians and 99.0 per cent. in all patients. Re-infections were found in five male civilians, four female civilians, and one sailor. Reinfection rates in male civilians, female civilians, sailors, and in all patients were $2 \cdot 6,2 \cdot 3,1 \cdot 9$, and 2.4 per cent. respectively. The total recurrence rate within 2 weeks (relapse rate + re-infection rate) was therefore 4.7 per cent. in male civilians, 2.3 per cent. in female civilians, 1.9 per cent. in sailors, and 3.4 per cent. in all patients.

In all four patients with relapses, strains relatively resistant to ampicillin (MIC $\geqslant 0.16 \mu \mathrm{g} . / \mathrm{ml}$.) were isolated. In three the MIC was $0.64 \mu \mathrm{g} . / \mathrm{ml}$. and in one it was $0.16 \mu \mathrm{g} . / \mathrm{ml}$. Of the ten patients with re-infections, eight had sensitive strains and two relatively sesistant strains (MIC of $0.64 \mu \mathrm{g} . / \mathrm{ml}$. in both). In the latter two patients the strains isolated after treatment were highly sensitive to ampicillin. In all other patients with relapses and re-infections the sensitivities to ampicillin of the strains isolated before and after treatment did not differ by more than one dilution.

All four patients with relapses were successfully treated with tetracycline $\mathrm{HCl}, 2 \mathrm{~g}$. daily for 5 days:

In the follow-up period after 2 weeks and within 3 months, 65 patients returned with gonococcal infections. In fifty of these 65 patients, the recognition of the gonococcal infection was preceded by one or more negative examinations. In only fifteen patients (eleven male civilians and four female civilians) had no previous examination taken place. All 65 patients admitted re-exposure to risk of infection. Together with the ten re-infections seen within the first 2 weeks, there was thus a total of 75 patients with re-infections (33 male civilians, 37 female civilians, and 5 sailors). The total re-infection rate within 3 months after treatment amounted to $14 \cdot 6$ per cent. in male civilians, 19.6 per cent. in female civilians, 9.1 per cent. in sailors, and 15.9 per cent. in all patients. All 75 patients with re-infections were retreated with our standard ampicillin treatment; 39 returned at least once within 2 weeks of retreatment and cultures were negative in all.

During the 3 months after treatment, 42 male civilians (18.5 per cent. of all male civilians) and eight sailors (14.5 per cent. of all sailors) were treated for a post-gonococcal urethritis with tetracycline $\mathrm{HCl} 2 \mathrm{~g}$. daily for 5 days.

Ampicillin serum levels in six male patients (A, $\mathrm{B}, \mathrm{C}, \mathrm{D}, \mathrm{E}$, and $\mathrm{F}$ ) treated with $1 \mathrm{~g}$. ampicillin intramuscularly, followed by $2 \mathrm{~g}$. ampicillin $4 \mathrm{hrs}$ later are presented in Figs 1 and 2. Three patients
(A, B, and C) had fasted overnight before the start of treatment and were not allowed to take any food or drink until $10 \mathrm{hrs}$ after the start of treatment. Their ampicillin serum levels are presented in Fig. 1.

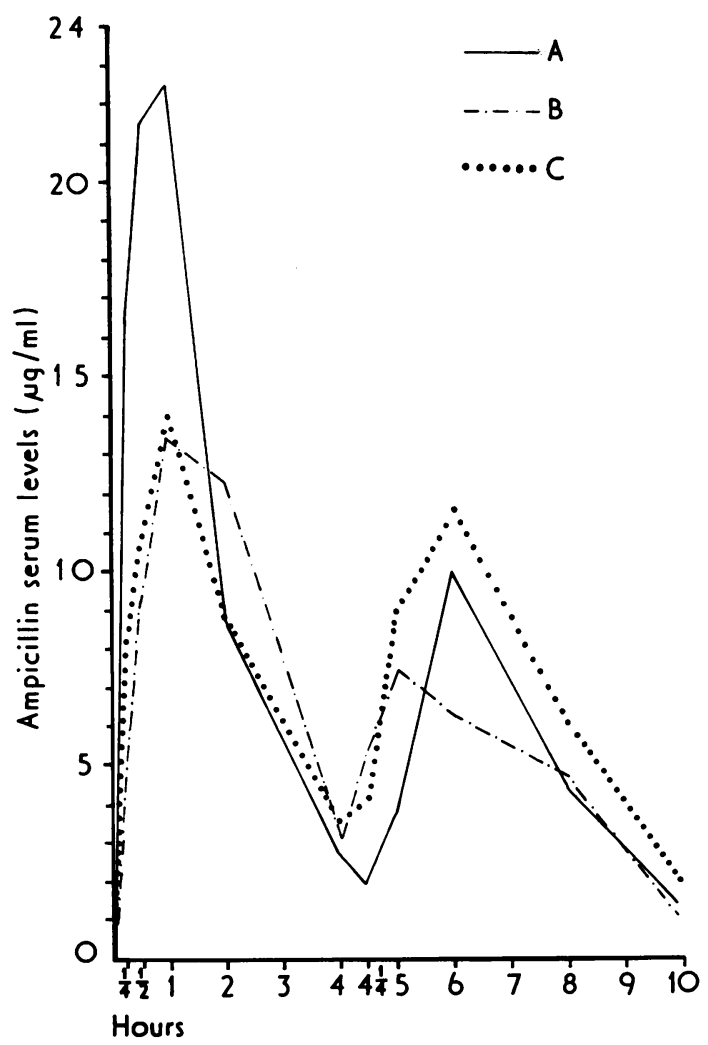

FIG. 1 Ampicillin serum levels in three patients $(A, B$, and $C)$, who had fasted overnight before the start of treatment and who were not allowed to take any food or drink until $10 \mathrm{hrs}$ after the start of treatment. Treatment consisted of $1 \mathrm{~g}$. ampicillin intramuscularly followed by $2 \mathrm{~g}$. ampicillin orally 4 hrs later

The other three patients (D, E, and F) had also fasted overnight before the start of treatment, but were allowed to take a light breakfast $15 \mathrm{~min}$. before the oral dose. Their ampicillin serum levels are presented in Fig. 2.

Wide variations in ampicillin serum values were found. Two patients ( $A$ and $E$ ) showed very high levels after the injection of $1 \mathrm{~g}$. ampicillin. Peak levels after injection were noticed after $1 \mathrm{hr}$ in patients $\mathrm{A}$, $\mathrm{B}, \mathrm{C}, \mathrm{E}$, and $\mathrm{F}$ and after $2 \mathrm{hrs}$ in patient D. Peak 


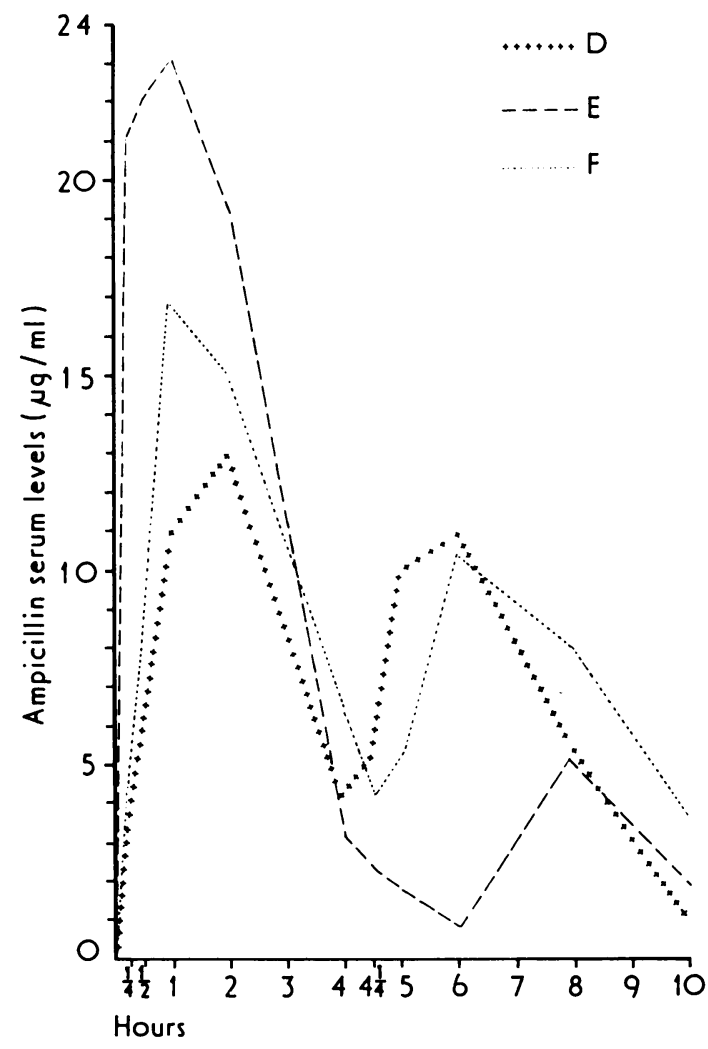

FIG. 2 Ampicillin serum levels in three patients $(D, E$, and $F)$ who had fasted overnight before the start of treatment and who were allowed a light breakfast $15 \mathrm{~min}$. before the oral dose of ampicillin. Treatment consisted of $1 \mathrm{~g}$. ampicillin intramuscularly followed by $2 \mathrm{~g}$. ampicillin orally 4 hrs later

levels after the oral dose of $2 \mathrm{~g}$. given $4 \mathrm{hrs}$ after the injection were noticed after $1 \mathrm{hr}$ in patient $B$, after $2 \mathrm{hrs}$ in patients $\mathrm{A}, \mathrm{C}, \mathrm{D}$, and $\mathrm{F}$, and after $4 \mathrm{hrs}$ in patient E. Patient $\mathrm{E}$ absorbed the orally administered ampicillin very slowly. The light breakfast did not seem to have any significant effect on the serum levels achieved (Fig. 2).

The MICs of ampicillin for the strains of $N$. gonorrhoeae isolated in the six patients A, B, C, D, E, and $F$ were respectively: $0.64,0 \cdot 16,0.005,0.64,0.01$ and $0.01 \mu \mathrm{g} . / \mathrm{ml}$. All these patients were cured.

\section{Discussion}

A high defaulter rate for male civilians $(20.6$ per cent. compared with 6.4 per cent. for female civilians) was found in the civilian population in the Rotterdam outpatient department. The higher percentage of defaulters in males can partially be explained by the fact that males without symptoms after treatment often assume that they are cured and no further examination is necessary, while females, frequently symptomless before treatment, are anxious to know whether they are cured or not. High re-infection rates within 3 months (14.6 per cent. in male civilians and 19.6 per cent. in female civilians) are, like high defaulter rates, a common characteristic of large venereal diseases clinics. In patients treated for gonorrhoea, Willcox (1963) reported a re-infection rate within 3 months of 11 per cent. (St. Mary's Hospital, London). In our study the majority of patients with re-infections were re-infected by their regular consorts. Some of these consorts were not named by the patients in the first interview and others refused to visit a physician. These findings imply that, in the Rotterdam outpatient department, intensified contact tracing is of the utmost importance to reduce the re-infection rate.

A high cure rate of 99 per cent. was found in all patients ( 97.9 per cent. in male civilians, 100 per cent. in female civilians and sailors) who returned within 2 weeks. These results are comparable with those of other ampicillin treatment schedules reported by Keys and others (1969), Gundersen and others, (1969), and Eriksson (1971).

All four patients with relapses harboured strains of $N$. gonorrhoeae relatively resistant to ampicillin. The majority ( 8 out of 10 ) of strains isolated in patients with re-infections within 2 weeks were, on the contrary, sensitive to ampicillin. Of 388 strains from patients who returned within 2 weeks, 247 strains ( 63.6 per cent.) were sensitive and 141 strains (36.4 per cent.) were relatively resistant to ampicillin. For 175 strains from male civilians, the corresponding numbers were 113 strains ( 64.5 per cent.) sensitive and 62 strains ( 35.5 per cent.) relatively resistant to ampicillin (Table II).

According to these findings, male civilian patients with strains of $N$. gonorrhoeae relatively resistant to ampicillin are more prone to relapses than male civilian patients with strains sensitive to ampicillin $\left(\chi^{2}=4.85 ; P<0.05\right)$. Eriksson and Wallmark (1972), on the contrary, observed therapeutic failures with oral ampicillin treatment both when the strains were sensitive and when they were relatively resistant to the antibiotic.

Eickhoff, Kislak, and Finland (1965) and Klein and Finland (1963) ascertained ampicillin serum levels by the agar diffusion method using Sarcina lutea (described by Grove and Randall, 1955) after a single intramuscular injection of $1 \mathrm{~g}$. ampicillin in ten 
normal young men. Average ampicillin serum levels in blood samples drawn $\frac{1}{2}, 1,2$, and $4 \mathrm{hrs}$ after injection were $9 \cdot 27,10 \cdot 10,7 \cdot 28$, and $2.52 \mu \mathrm{g} . / \mathrm{ml}$. respectively (Eickhoff and others, 1965). These values are considerably lower than those obtained in our six patients.

The difference might be explained by the fact that our six patients were confined to bed during the trial. Eriksson (1971) recorded a personal communication of Wahlqvist and Lönell that serum concentrations twice as high and more sustained were found in patients confined to bed than in healthy volunteers. Eriksson (1971) ascertained blood serum levels, using the method described by Grove and Randall (1955), after the oral administration of $2 \mathrm{~g}$. ampicillin in one dose in twelve healthy male volunteers. Average mean ampicillin serum levels and standard errors after $2,3,5$, and $8 \mathrm{hrs}$ were $8.85 \pm 0.93,7.50 \pm 0.71$, $2.42 \pm 0.35$, and $0.29 \pm 0.049 \mu \mathrm{g}$. $/ \mathrm{ml}$. respectively. In our patients, oral treatment was given $4 \mathrm{hrs}$ after injection and therefore the results are not comparable. We found wide variations in ampicillin serum values (Figs 1 and 2). Eriksson (1973) also stressed the fact that these variations can be found with both oral and intramuscular treatment. However, with the exception of patient $\mathrm{E}$, ampicillin serum levels were high over a period of $8 \mathrm{hrs}$ in comparison with the MICs of ampicillin for the strains of $N$. gonorrhoeae in our patients $(0.005 \mu \mathrm{g} . / \mathrm{ml}$. $\leqq M I C \leqq 0.64 \mu \mathrm{g} . / \mathrm{ml}$.). Eriksson (1971) estimated that a minimum effective duration of 5 to $12 \mathrm{hrs}$, and most likely 7 to $8 \mathrm{hrs}$, and a minimum ratio between maximum serum concentration and MIC of two to five times, was required for successful ampicillin therapy. The treatment described in this paper satisfied both conditions.

\section{Summary}

In a series of 417 patients ( 245 men and 172 women) followed-up after treatment for gonorrhoea, a cure rate of 99 per cent. was obtained using $1 \mathrm{~g}$. ampicillin intramuscularly followed by an oral dose of $2 \mathrm{~g}$. ampicillin $4 \mathrm{hrs}$ later. In the four patients with relapses, strains of $N$. gonorrhoeae relatively resistant to ampicillin (MIC $\geqslant 0.16 \mu \mathrm{g} . / \mathrm{ml}$.) were isolated. Ampicillin serum levels were measured in six of the male patients.
We wish to thank Mrs. H. G. F. Zwart, Mrs. M. P. E. de Jonge-Suy, Mrs. S. de Weerdt-van Ameyden, Mrs. G. G. Koejemans-Meiborg, Mr. H. D. Bruning, and Mr. R. van Strik for their technical assistance.

\section{References}

EickHoff, C., Kislak, J. W., and Finland, M. (1965) Amer. F. med. Sci., 249, 163

ERICsSON, H. M., and SHERRIS, J. C. (1971) Acta path. microbiol. scand., Section B, Suppl. 217

ERIKsson, G. (1970a) Acta derm.-venereol. (Stockh.), 50, 451

- (1970b) Ibid., 50, 461

- (1971) Ibid., 51, 305

- (1973) Brit. f. vener. Dis., 49, 353

- and WallmaRK, G. (1972) Acta derm.-venereol. (Stockh.), 52, 419

Grove, D. C., and Randall, W. A. (1955) 'Methods of Assay of Antibiotics', p. 14. Medical Encyclopedia Inc., New York

Gundersen, T., ØDEgaARD, K., and GJessing, H. C. (1969) Brit. F. vener. Dis., 45, 235

KerCull, R. G. (1968) Milit. Med. (Wash.), 133, 985

KeYs, T. F., Halverson, C. W., and Clarke, E. J. (1969) f. Amer. med. Ass., 210, 857

Klein, J. O., and Finland, M. (1963) Amer. f. med. Sci., 245, 544

MicheL, M. F., van WaARdHUIZEN, J. P., and KeRREBiJN., K. F. (1973) Chemotherapy, 18, 77

Stclz, E., ZWART, H. G. F., and Michel, M. F. (1974) Brit. f. vener. Dis., 50, 202

ThaYeR, J. D., and Martin, J. E. (1966) Publ. Hlth Rep. (Wash.), 81, 559

WILlcox, R. R. (1963) Curr. Med. Drugs, 3, no. 12, p. 3 -, WoOdCOCK, K. R., LATTO, D., JoHN, J., ReDMOND, A., PARKER, R. B., ReES, G. D., and Cobbold, R. J. C. (1973) Brit. F. vener. Dis., 49, 263

WOLS-VAN DER WIELEN, A. (1971) Ibid., 47, 190

Emploi d'une association d'ampicilline intramusculaire et buccale dans le traitement de la gonococcie

\section{SOMMAIRE}

Sur une série de 417 gonococciques ( 245 hommes et 172 femmes) suivis après traitement, on obtint un taux de guérison de 99 pour cent par l'emploi de $1 \mathrm{~g}$ d'ampicilline intra-musculaire suivi, quatre heures après, d'une dose buccale de $2 \mathrm{~g}$ d'ampicilline.

Chez les 4 malades ayant rechuté, on isola des souches de $N$. gonorrhoeae relativement résistantes à l'ampicilline $(\mathrm{CMI} \geqslant 0,16 \mu \mathrm{g} / \mathrm{ml})$. Le taux sanguin de l'ampicilline fut mesuré pour six des malades hommes. 